\title{
Reuse of Nitric Acid in the Oxidative Pretreatment Step for Preparation of Humic Acids from Low Rank Coal of Mukah, Sarawak
}

\author{
Sim Siong Fong,* Lau Seng and Haslinda Bt Mat
}

\author{
Faculty of Resource Science \& Technology, University Malaysia Sarawak, 94300 Kota Samarahan, \\ Sarawak, Malaysia
}

\begin{abstract}
O ácido nítrico é um material eficiente na produção de ácidos húmicos. Contudo, é um item caro que torna o processo desfavorável industrialmente. Estudos indicaram que existe a possibilidade de re-utilização do ácido nítrico para oxidação; entretanto, as estruturas resultantes dos ácidos húmicos não foram estudadas. Por isso, o objetivo deste estudo foi investigar as propriedades espectroscópicas e químicas dos ácidos nitro-húmicos preparados com ácido nítrico re-utilizado. A amostra de carvão foi oxidada com ácido nítrico 5\%, 10\% e $15 \%$ com posterior extração dos ácidos nitro-húmicos. A concentração de ácido nítrico com melhores rendimentos foi empregada novamente em outros 2 ciclos de oxidação. As propriedades químicas e espectroscópicas dos ácidos nitro-húmicos foram avaliadas. Os resultados indicaram que o processo de oxidação geralmente melhora as propriedades funcionais ácidas dos ácidos nitro-húmicos, sendo que ácido nítrico a 10\% produziu os melhores rendimentos. $\mathrm{O}$ ácido nítrico foi re-utilizado na extração, com bom rendimento, em torno de $78 \%$. Estruturalmente, os ácidos nitro-húmicos produzidos com o ácido nítrico reutilizado apresentaram tamanhos moleculares maiores e menos grupos funcionais ácidos, sugerindo um menor fracionamento da estrutura.
\end{abstract}

Nitric acid is an effective material for production of humic acids. Nevertheless, it is an expensive item that renders the process unfavorable industrially. Study indicated that there was a possibility to reuse the nitric acid for oxidation however the resulting structures of humic acids was not studied. Therefore, the objective of this study was to investigate the chemical and spectroscopic properties of nitrohumic acids prepared with reused nitric acid. The coal sample was oxidized with $5 \%, 10 \%$ and $15 \%$ of nitric acid and subjected to extraction for nitrohumic acids. Concentration of nitric acid with the most yields was reemployed for another 2 cycles of oxidation. The chemical and spectroscopic properties of nitrohumic acids were evaluated. The results indicated that oxidation process generally improved the acidic functional properties of the nitrohumic acids with $10 \%$ nitric acid producing the most promising yield. The nitric acid was reused for extraction and the percentage yield remained good at an average of $78 \%$. Structurally, the nitrohumic acids produced with the reused nitric acid demonstrated larger molecular size and fewer acidic functional groups suggesting lesser extent of structure fractionation.

Keywords: coal, nitrohumic acids, reuse, nitric acid

\section{Introduction}

Application of humic acids in agriculture as soil fertilizer and soil conditioner has been extensively discussed in the literatures. To date, numerous researches have demonstrated conclusively that humic substances have significant impacts on the soil structure and plant

*e-mail: sfsim@frst.unimas.my growth. Humic acids are found to possess ability to inhibit the formation of insoluble Ca phosphates and thus enhance phosphorus bioavailability. ${ }^{1}$ The high content of oxygen containing functional groups, particularly carboxyl and phenolic groups could act as ion exchange site for $\mathrm{pH}$ buffering, nutrient transport and chelating phytotoxic aluminum. ${ }^{2}$ Mato et al. ${ }^{3}$ and Pflud and Ziechman ${ }^{4}$ found that acidic functional groups of humic substances were related to biochemical activity. Vaughan et al. ${ }^{5}$ and Nardi et $a .^{6}{ }^{6}$ in addition, established that the low molecular size 
humic acids components are effective in enhancing plant metabolism.

In regard to the potential of the humic acids, continuous development has led to availability of various commercial humic acid based products and they are widely marketed. The humic acids products are usually available in the form of inexpensive soluble salts, referred to as potassium humate. ${ }^{7}$ The research advancements on the application of coal resources for agronomic purposes have instigated investigation on the low rank coal of Sarawak in which the agriculture potential of the source is scarcely known. According to Novák et al., ${ }^{8}$ alkaline extraction, acid precipitation and membrane separation are the techniques involved in preparation of cost effective and large scale production of humate. Based typically on the acid base fractionation approach, the humic acids from the low rank coal of Sarawak were extracted. The yield reported was economically unsustainable with an average of $20 \% .{ }^{9}$ In Czech Republic, an average of $70 \% \mathrm{~m} / \mathrm{m}$ humic acids was obtained from oxidized lignite, therefore comparatively; the essential yield of humic acids attained from the indigenous coal was insignificant. ${ }^{10}$

Oxidation is commonly known to enhance the humic acids content of the source. In light of that, various processes have been developed to chemically oxidize coal resources to produce greater yield of humic acids. A new process of dry oxidative depolymerization was revealed to convert coal resources into high yield of humic acids with abundant chemically active functional groups. ${ }^{11}$ A substantial increase in yield was achieved with the oxyhumic acids on tomatoes, wheat and maize (5-25\%). Another process, the oxygen/ air driven wet oxidative approach similarly had resulted in $85 \%$ humic acids yield. ${ }^{12}$ Nitric acid oxidation is an older oxidation process yet potentially valuable for deriving useful humic substances. The major setback of the process is its production cost and studies indicated doubtful economic potential of this process. ${ }^{13,14}$ However, in another study, Riera et al. ${ }^{15}$ indicated the possibility of reusing the nitric acid for multiple extraction/oxidation processes before significant decrease in the oxidation capacity. The present study attempted to investigate the possibility of reusing the nitric acid for extraction of nitrohumic acids from the low rank coal of Sarawak. The study evaluated the optimum concentration of nitric acid for extraction of nitrohumic acids. The filtrate liquor of nitric acid with the most yields was reused for another 2 cycles of oxidation. The yields, chemical and spectroscopic characteristics of the nitrohumic acids were examined.

\section{Experimental}

\section{Preparation of coal sample}

Mukah coal sample was pulverized and sieved through $50 \mu \mathrm{m}$ sieve, The retained sample was kept for oxidation and extraction process.

\section{Oxidation with nitric acid $\left(\mathrm{HNO}_{3}\right)$}

The sieved coal sample was oxidized with nitric acid of $5 \%, 10 \%$ and $15 \%$ concentrations ( $1 \mathrm{~g}$ coal with $5 \mathrm{~mL}$ of nitric acid) for $2 \mathrm{~h}$ at $70{ }^{\circ} \mathrm{C}$. The residual coal mixture was filtered, washed and dried at $105{ }^{\circ} \mathrm{C}$ for $24 \mathrm{~h}$. According to Kurata and Oyamada, ${ }^{20}$ oxidation of lignite with nitric acid was almost completed in an hour.

\section{Extraction of humic acids}

The humic acids were extracted according to the standard procedure described by Swift with modifications. ${ }^{16}$ One gram of coal was treated with $10 \mathrm{~mL}$ of $0.5 \mathrm{~mol} \mathrm{~L}{ }^{-1} \mathrm{KOH}$ at $70{ }^{\circ} \mathrm{C}$ for $2 \mathrm{~h}$. The supernatant was filtered through $50 \mu \mathrm{m}$ sieve and the coal residue was washed with distilled water until the supernatant was clear. The supernatant was acidified with concentrated $\mathrm{H}_{2} \mathrm{SO}_{4}$ to $\mathrm{pH} \mathrm{1-2}$ and allowed to stand for $24 \mathrm{~h}$. The precipitated humic acids were separated by centrifugation. The gel-liked humic acids were oven-dried at $60{ }^{\circ} \mathrm{C}$ and stored in desiccators. The humic acids prepared with nitric acid oxidation were referred to as ntirohumic acids.

\section{Reuse of nitric acid}

Reuse of nitric acid refers to employing the nitric acid from one cycle of oxidation process for multiple cycle of oxidation. Fresh nitric acid at 5\%,10\% and 15\% was employed for oxidation and the oxidized coal was subjected to extraction of humic acids. The concentration of nitric acid with the most yields was reused for another 2 cycles of oxidation. The products of the extraction were designated as reuse (x1)-HA and reuse (x2)-HA.

\section{Weight losses}

Weight losses (on dry basis) of the coal samples were determined as follow:

Weight losses, $\%=\frac{(\mathrm{g} \text { coal })-(\mathrm{g} \text { residual coal })}{(\mathrm{g} \text { coal })} \times 100$ 


\section{Yield of nitrohumic acids}

The yield of crude nitrohumic acids was calculated as the weight of extracted nitrohumic acids per unit weight of coal.

\section{Chemical characterization}

The moisture content was determined by drying the samples at $105{ }^{\circ} \mathrm{C}$ overnight. The ash content was determined by combustion of the samples at $800{ }^{\circ} \mathrm{C}$ for 2 h. ${ }^{17}$ The total acidity was measured using the barium hydroxide method and the carboxyl groups were determined by using calcium acetate method. The phenolic content was calculated as the difference between the total acidity and the carboxyl groups. ${ }^{18}$

\section{Spectroscopic characterization}

\section{FTIR}

FTIR spectra of the samples were recorded on $\mathrm{KBr}$ pellets ( $2 \mathrm{mg}$ nitrohumic acids and $100 \mathrm{mg} \mathrm{KBr}$ ) using FTIR spectrophotometer. All of the spectra were selfdeconvoluted to improve the apparent resolution. For the study of the integrated area in the region of 1780-1500 $\mathrm{cm}^{-1}$, the spectra were self deconvoluted at Gamma factor of 2 and smoothing factor of 50\%. Spectra comparison was performed with the software of Spectrum GX.

\section{$U V$-Vis}

Approximately $5.0 \mathrm{mg}$ of nitrohumic acids samples were dissolved in $25 \mathrm{~mL}$ of $0.05 \mathrm{~mol} \mathrm{~L}^{-1} \mathrm{NaHCO}_{3}$ solutions with $\mathrm{pH}$ adjusted to $8-9$ with $0.1 \mathrm{~mol} \mathrm{~L}^{-1}$ $\mathrm{NaOH}$ to assist solubility. Absorbance at $400 \mathrm{~nm}, 465$ $\mathrm{nm}, 600 \mathrm{~nm}$ and $665 \mathrm{~nm}$ were recorded. The $\mathrm{E}_{4} / \mathrm{E}_{6}$ value was calculated based on the ratio of absorbance at 465 $\mathrm{nm}$ and $665 \mathrm{~nm}$. Absorbance at $465 \mathrm{~nm}$ expresses the presence of humic acids formed in initial humification stage and absorbance at $665 \mathrm{~nm}$ indicates presence of humic acids formed in well-humified organic matter. ${ }^{19}$

\section{Statistical analysis}

Post Hoc test of ANOVA was employed to evaluate the experimental results.

\section{Results and Discussions}

\section{Yield of nitrohumic acids}

Table 1 summarizes the yield of nitrohumic acids in relation to the concentration of nitric acid. Oxidation process undoubtedly had improved the yield substantially with loss of oxidation corresponded to the concentration. The nitric acid could have manipulated the solubility of nitrohumic acids by introducing acid groups to the structures and rendered them more readily attacked by alkaline solution during extraction. The yield of nitrohumic acids as noted were governed by the concentration and experimental results suggested that nitric acid at $10 \%$ produced the most promising yield. The optimum concentration for extraction of nitrohumic acids is not well understood as inconsistent data was constantly reported. Kurata and Oyamada ${ }^{20}$ obtained better yield with $7 \%$ nitric acid; however, Won ${ }^{21}$ recommended $15 \%$.

Table 1. Yield of nitrohumic acids

\begin{tabular}{lcc}
\hline Humic acids & Loss upon oxidation/(\%) & Crude Yield/(\%) \\
\hline $5 \% \mathrm{HNO}_{3}$ & 12.6 & $88.4 \pm 12.6$ \\
$10 \% \mathrm{HNO}_{3}$ & 13.4 & $93.2 \pm 2.6$ \\
$15 \% \mathrm{HNO}_{3}$ & 19.5 & $82.9 \pm 0.9$ \\
Reference HA & - & $10.0 \pm 1.0$ \\
\hline
\end{tabular}

\section{Chemical and spectroscopic characteristics of nitrohumic} acids

Table 2 presents the chemical and spectroscopic characteristics of nitrohumic acids. Generally, oxidation triggered several changes, which include increased acidic functional groups and decreased molecular size possibly due to structure fractionation. The intensity of the cleavage was observed to increase with the nitric acid concentration as suggested by the $\mathrm{E}_{4} / \mathrm{E}_{6}$ value. Upon oxidation, enrichment of carboxyl groups and substitution of nitrogen occurred leading to the formation of nitrohumic acids with a variety of aliphatic dicarboxylic acids, benzenecarboxylic acids, hydroxybenzoic acids and nitro compounds. ${ }^{22}$ In terms of ash, the oxidized humic acids demonstrated relatively lower ash compared to the reference humic acids (humic acids prepared without undergoing oxidation process). Nitric acid treatment was associated with organic matter solubilization, which was seen as a decrease in ash content. ${ }^{23}$ The nitric acid molecules react with inorganic matter, mostly clay and carbonate minerals leading to acid consumption. ${ }^{24}$

Figure 1 illustrates the FTIR spectra of nitrohumic acids prepared with different concentration of nitric acid. It was evidenced that the band intensity at $1,700 \mathrm{~cm}^{-1}$ ascribed to the presence of carbonyl groups increases with the concentrations of nitric acid. This observation was in agreement with the experimental results of $-\mathrm{COOH}$ 
Table 2. Chemical and spectroscopic characteristics of humic acids

\begin{tabular}{|c|c|c|c|c|c|c|}
\hline Humic acids & Moisture/(\%) & $\mathrm{Ash} /(\%)$ & -COOH/(mequiv. $\left.\mathrm{g}^{-1}\right)$ & Phenolic OH/(mequiv. $\left.\mathrm{g}^{-1}\right)$ & Total acidity/(mequiv. $\mathrm{g}^{-1}$ ) & $\mathrm{E}_{4} / \mathrm{E}_{6}$ \\
\hline $5 \% \mathrm{HNO}_{3}$ & $10.49 \pm 0.13$ & $2.41 \pm 0.36$ & $3.97 \pm 1.49$ & $10.46 \pm 1.15$ & $14.43 \pm 0.44$ & 4.64 \\
\hline $10 \% \mathrm{HNO}_{3}$ & $14.92 \pm 0.13$ & $2.99 \pm 0.02$ & $7.70 \pm 1.75$ & $11.55 \pm 2.37$ & $19.25 \pm 1.58$ & 4.92 \\
\hline $15 \% \mathrm{HNO}_{3}$ & $16.05 \pm 0.15$ & $2.77 \pm 0.31$ & $7.57 \pm 0.52$ & $7.62 \pm 1.99$ & $15.2 \pm 1.53$ & 5.98 \\
\hline Reference HA & $5.80 \pm 0.90$ & $4.45 \pm 0.90$ & $1.52 \pm 0.06$ & $7.09 \pm 1.72$ & $8.60 \pm 1.70$ & 3.91 \\
\hline
\end{tabular}

content discussed earlier. The said band in addition; was observed to shift from $1,701 \mathrm{~cm}^{-1}$ to $1,717 \mathrm{~cm}^{-1}$ upon oxidation indicating that the carbonyl groups are prominently found within electrophilic molecules. ${ }^{23} \mathrm{An}$ ill defined shoulder band at $1,540 \mathrm{~cm}^{-1}$ attributed to amide II was noticed to become progressively significant with increased nitric acid concentration implying more intensified attack of nitro and nitroso groups. Upon nitric acid treatment, trace nitrate compounds are expected to be present and it was shown on the FTIR spectra as a weak absorption band at $1,397 \mathrm{~cm}^{-1}$. Several additional bands with relatively strong intensities below $1,100 \mathrm{~cm}^{-1}$ was observed on the FTIR spectra of nitrohumic acids, distinguishing the oxidized products from the reference compound. Absorption bands at $1,069 \mathrm{~cm}^{-1}$ and $1,008 \mathrm{~cm}^{-1}$ are likely referred to the presence of mineral constituents or polysaccharides. Two out-of-plane $\mathrm{C}-\mathrm{H}$ deformation bands were observed in the region of $900-700 \mathrm{~cm}^{-1}$. These bands were assigned to aromatic structures with one to two no substituted hydrogen atoms. As documented, it is inappropriate to quantify the aromatic hydrogen based on the absorption band in this region as the out-of-plane $\mathrm{N}=\mathrm{O}$ deformation bands and the $\mathrm{C}-\mathrm{H}$ tensions bands are also appeared in the same zone..$^{23}$

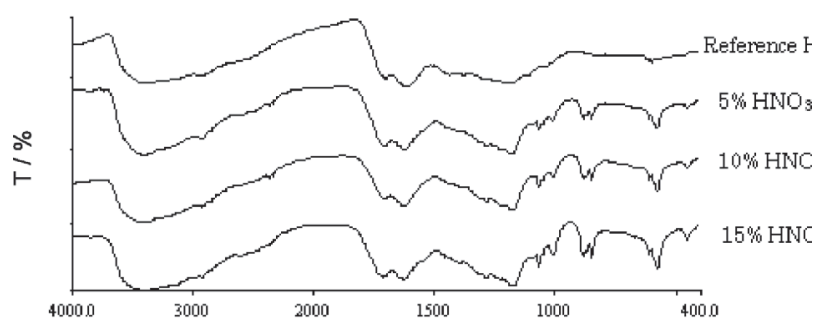

Figure 1. FTIR spectra of humic acids prepared with various concentration of nitric acid.
Yield and characteristics of nitrohumic acids prepared with used nitric acid

Reusing nitric acid for oxidation produced nitrohumic acids with considerable different properties as indicate in Table 3. Apparently, a reduced extraction yield was observed indicating loss of oxidation capacity, however, reasonable yield could still be achieved with the first batch of filtrate liquor. The acidity of the products and weight losses incurred was decreased with the increase in the frequency of acid being reused. This was in agreement with the work of Riera et al. ${ }^{15}$ Post Hoc test revealed no significant different $(\mathrm{p}>0.05)$ in the carboxyl and phenolic $\mathrm{OH}$ contents of nitrohumic acids prepared with fresh nitric acid and first batch of used nitric acid implying resemblance of the extracts in term of the acidic functional properties.

Structurally, nitrohumic acids extracted with used nitric acid demonstrated relatively higher molecular size as suggested by the $E_{4} / E_{6}$, indicative of lesser extent of structure fractionation. The FTIR spectra of nitrohumic acids prepared with fresh and used nitric acid (first batch and second batch) are shown in Figure 2. The structural features of the nitrohumic acids were evaluated according to Yürüm and Altuntaş. ${ }^{25}$ The absorption bands in the regions between $1,780 \mathrm{~cm}^{-1}$ and $1,500 \mathrm{~cm}^{-1}$ were subdivided into 9 sub-regions with functional bands assignment referred to Calemma et al. ${ }^{26}$ and Shevla. ${ }^{27}$ The spectra were self deconvoluted and the integrated areas of a definite functional group bands in different spectra were compared as relative measures of the amount of the relevant groups in different samples.

Table 4 indicates the evolution of peak area for respective functional bands of nitrohumic acids prepared with fresh and used nitric acid. The nitrohumic acids

Table 3. Yield and characteristics of humic acids prepared with used nitric acid

\begin{tabular}{|c|c|c|c|c|c|c|c|c|}
\hline Humic acids & Loss/(\%) & Crude Yield/(\%) & Moisture/(\%) & $\mathrm{Ash} /(\%)$ & $\begin{array}{c}\text {-COOH/ } \\
\text { (mequiv. } \mathrm{g}^{-1} \text { ) }\end{array}$ & $\begin{array}{l}\text { Phenolic } \mathrm{OH} / \\
\text { (mequiv. } \mathrm{g}^{-1} \text { ) }\end{array}$ & $\begin{array}{l}\text { Total acidity/ } \\
\text { (mequiv. } \mathrm{g}^{-1} \text { ) }\end{array}$ & $\mathrm{E}_{4} / \mathrm{E}_{6}$ \\
\hline $10 \% \mathrm{HNO}_{3}$ & 13.4 & $93.15 \pm 2.62$ & $14.92 \pm 0.13$ & $2.99 \pm 0.02$ & $7.70 \pm 1.75$ & $11.55 \pm 2.37$ & $19.25 \pm 1.58$ & 4.92 \\
\hline Reuse (x1) & 9.5 & $78.20 \pm 1.21$ & $11.32 \pm 0.35$ & $2.78 \pm 0.08$ & $5.73 \pm 0.33$ & $7.75 \pm 0.70$ & $13.48 \pm 0.78$ & 3.49 \\
\hline Reuse (x2) & 5.2 & $6.33 \pm 0.12$ & $7.38 \pm 0.79$ & $5.01 \pm 0.10$ & $2.88 \pm 0.18$ & $7.30 \pm 1.33$ & $10.18 \pm 1.15$ & 4.23 \\
\hline
\end{tabular}


Table 4. Peak area of respective functional bands of humic acids prepared with fresh and reused nitric acid

\begin{tabular}{|c|c|c|c|c|}
\hline Region $/ \mathrm{cm}^{-1}$ & $10 \% \mathrm{HNO}_{3}-\mathrm{HA}$ & Reuse $(\times 1)$ & Reuse $(\times 2)$ & Reference HA \\
\hline 1,780-1,760 (Ar-O-CO-R) & 898.46 & 538.88 & 658.29 & 634.42 \\
\hline 1,755-1,740 (R-O-CO-R) & 233.61 & 185.17 & 196.08 & 351.62 \\
\hline 1,740-1,720 (Ar-O-CO-Ar) & 402.37 & 320.64 & 315.31 & 249.82 \\
\hline 1,715-1,705 (Ar-CHO) & 213.27 & 89.93 & 170.50 & 58.31 \\
\hline 1,700-1,692 (Ar-COOH) & 120.57 & 99.49 & 81.77 & 63.74 \\
\hline 1,690-1,655 (Quinone $2 \mathrm{CO}$ ) & 664.25 & 561.59 & 465.62 & 395.41 \\
\hline 1,655-1,635 (Ar-CO-Ar) & 575.49 & 117.7 & 151.66 & 209.68 \\
\hline 1,630-1,565 (aromatic stretching) & 1343.52 & 885.3 & 602.05 & 457.71 \\
\hline $1,540-1,500\left(\mathrm{COO}^{-} \mathrm{M}^{+}\right)$ & 1324.92 & 938.7 & 656.43 & 749.12 \\
\hline
\end{tabular}

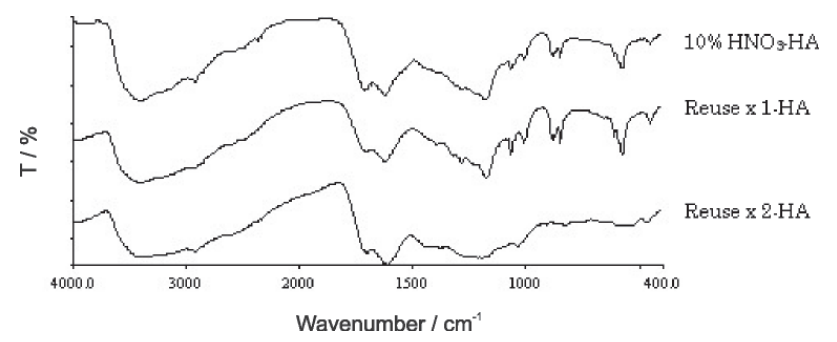

Figure 2. FTIR spectra of humic acids prepared with fresh and reused nitric acid.

prepared with used nitric acid consistently demonstrated declination in the peak area for all of the functional bands investigated. The reactions of nitric acid oxidation on coal as suggested by Yidirim \& Özbayoğlu ${ }^{24}$ are simplified in reaction 1 and reaction 2. Basically, the reaction initiates with nitric acid providing nitro and nitroso groups as well as internal oxygen. These compounds attack on the aromatic rings leading to carboxylic, nitro and nitroso substitution.

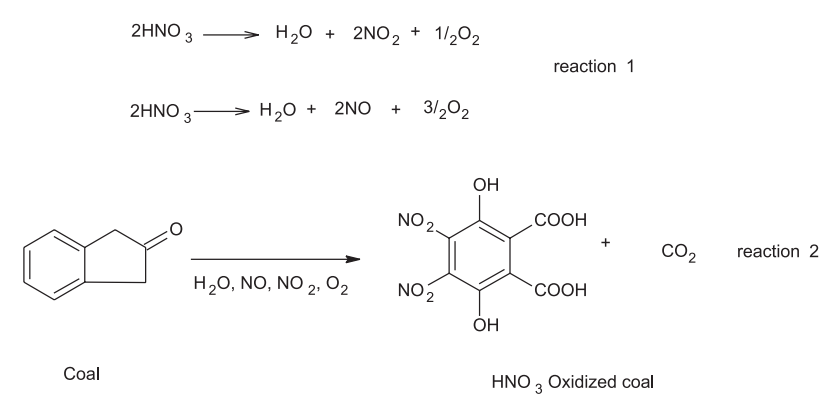

For used nitric acid, the oxidation capacity has certainly been reduced due to acid consumption explaining the diminishing peak area of the functional bands. Peak area of aromatic ketones $\left(1,655-1,635 \mathrm{~cm}^{-1}\right)$ and aromatic stretching $\left(1,630-1,565 \mathrm{~cm}^{-1}\right)$ were observed to associate with the greatest reduction at an average of $76.59 \%$ and $44.65 \%$, respectively. Upon oxidation, disintegration of nitrohumic acids into aromatic compounds is one of the most prominent reactions. The progressive reduction observed in aromatic compounds of nitrohumic acids prepared with used nitric acid clearly suggests that structure fractionation occurred to a lesser extent likely attributed to the reduced oxidation capacity. Theoretical considerations and experimental evidence revealed that benzylic methylene and methylene next to -OR groups were the sites most susceptible to oxidation. ${ }^{28,29}$ Upon oxidation, the methylene groups are usually transformed into aromatic ketones. ${ }^{25}$ Based on the evolution of peak area of aromatic ketones on FTIR spectra, it is concluded that used nitric acid had apparently losing its oxidation capacity as less methylene groups were attacked upon oxidation thus producing lesser aromatic ketones.

\section{Conclusions}

As concluded by Riera et al..${ }^{15}$ the filtrate liquors obtained from one cycle of nitric acid oxidation were possible to be reused thus improving the economic viability of the process. The results of the present study likewise supported the recommendation. The percentage yields of nitrohumic acids produced from the first batch of reused filtrate liquors remained good at an average of $78 \%$. The yields were reduced dramatically with the second batch of reused filtrate liquors. Although reusing the nitric acid generated promising yields, the extracts demonstrated somewhat structure dissimilarities with the nitrohumic acids prepared with the fresh nitric acid. The extracts prepared with the reused nitric acid were larger in molecular size and fewer in acidic functional groups. Therefore, employing humic acids prepared with reused nitric acid for certain application, for example as soil conditioner, may require further investigation to confirm its effectiveness.

\section{Acknowledgment}

The authors would like to thank the University Malaysia Sarawak for the financial support. 


\section{References}

1. Grossl, P. R.; Inskeep, W. P.; Soil Sci. Soc. Am. J. 1991, 55, 670.

2. Noble, A. D.; Randall, P. J.; Commun. Soil Sci. Plant Anal. 1998, 29, 3023.

3. Mato, M. C.; Olmedo, M. G.; Mendez, J.; Soil Biol. Biochem. 1972, 44, 466.

4. Pflug, W.; Ziechmann, W.; Soil Biol. Biochem. 1981, 13, 293.

5. Vaughan, D.; Chesire, M. V.; Mundie, C. M.; Trans. Biochem. Soc. 1974, 2, 126.

6. Nardi, S.; Concheri, G.; Dell' Agnola, D.; Scrimin, P.; Soil Biol. Biochem. 1991, 23, 833.

7. Imbufe, A. U.; Patti, A. F.; Burrow, D.; Surapaneni, A.; Roy Jackson, W.; Milner, A. D.; Geoderma 2005, 125, 321.

8. Novak, J.; Kozler, J; Janos, P.; Cezikova, J.; Tokarova, V.; Madronova, L.; React. Funct. Polym. 2001, 47, 101.

9. Fong, S. F.; Seng, L.; Chong, W. N.; Asing, J.; Md Nor, M. F.; Mohd Pauzan, A. S.; J. Braz. Chem. Soc. 2006, 17, 582.

10. Carlsen, L.; Thomsen, M.; Dobel, S.; Larsen, P.; Mogensen, B. B.; Hansen, P. E. In Humic Substances: Versatile Components of Plants, Soils and Water, Ghabbour, E. A.; Davies, G., eds.; The Royal Society of Chemistry: Cambridge, 2000.

11. Rausa, R.; Girardi, E.; Calemma, V.; Proceeding of the Sixth International Humic Substances Meeting, 1992.

12. Dekker, J.; Cronje, I. J.; Louwrens, H. B.; Swart, H.; Proceedings of the Seventh Annual International Coal Conference, Pittsburgh, 1990.

13. Patti, A. F.; Verheyen, T. V.; Douglas, L.; Wang, X.; Sci. Total Environ. 1992, 113, 49.

14. Coca, J.; Alvarez, R.; Fuertes, A. B.; Industrial \& Engineering Chemistry Product Research and Development 1984, 23, 620.
15. Riera, F. A.; Alvarez, R.; Coca, J.; Bioresour. Technol. 1991, $36,185$.

16. Swift, R. S.; In Methods of Soil Analysis Part 3: Chemical Methods (SSSA Book Series No.5); Spark D. L., ed.; SSSA and ASA: Madison, WI, 1996.

17. Allen, S. E.; Chemical Analysis of Ecological Materials, Blackwell Scientific: London, 1989.

18. Schnitzer, M.; Proceeding of the Symposium on Soil Organic Matter Studies, International Atomic Energy Agency: Vienne, 1977.

19. Debska, B.; Maciejewska, A.; Kwiatkowska, J.; Rostlinna Vyroba 2002, 48, 33.

20. Kurata, Y.; Oyamada, T.; Bulletin of the Yamagata University (Engineering) 1960, 6, 137.

21. Won, T. K.; J. Korean Chem. Soc. 1968, 13, 62.

22. Charmbury, H. B.; Eckerd, J. W.; Latorre, J. S.; Kinney, C. R.; Technical paper of the College of Earth and Mineral Sciences Publications, Pennsylvania State University, 1945, p. 105.

23. Alvarez, R.; Clemente, C.; Gómez- Limón, D.; Fuel 2003, 82, 2007.

24. Yidirim, M.; Özbayoğlu, G.; Fuel 1997, 76, 385.

25. Yürüm, Y.; Altuntaş, N.; Fuel 1998, 77, 1809.

26. Calemma,V.; Iwanski, P.; Rausa, R.; Girardi; Preprints papers - American Chemical Society, Division of Fuel Chemistry 1992, 37, 730 .

27. Shevla, G. In Comprehensive Analytical Chemistry; Shevla, G., ed., Elsevier: Amsterdam, 1976, vol. VI.

28. Russel, A. G. In Free Radicals; Kochi, K., ed., Wiley: London, 1973,vol. I.

29. Hungtinton, J. G.; Mayo, F. R.; Kirshen, N. A.; Fuel 1979, 58, 31.

Received: May 17, 2006

Web Release Date: October 3, 2006 